\title{
Implementation of School Based Management to Improve Education Quality (Case Study in Special Schools)
}

\author{
Muhammad Sayuti *, M. Saleh, A. Muhyani Rizalie \\ Master Program of Education Management, Universitas Lambung Mangkurat, Banjarmasin 70123, \\ Indonesia
}

Article history:

Submission September 2020

Revised December 2020

Accepted December 2020

${ }^{*}$ Corresponding author:

E-mail: sayutim43@gmail.com

\begin{abstract}
School-based Management is the most appropriate alternative concept for the concept of granting authority to schools by making it easier to implement educational services that accommodate children with spe-cial needs. This study aims to describe school-based management in-cluding the application of school autonomy; organizing creative and fun active learning; fostering community participation; and education-al quality achievements. descriptive qualitative phenomenology with a case study design in SLB-A Negeri 3 Martapura, Banjar Regency. Data collection techniques used interviews, observation, and documenta-tion. The results showed that schools implemented school autonomy in implementing school regulations regarding the discipline of all school members. innovative learning is PAKEM learning that applies the strategy and role of the teacher in learning. Fostering community participation through developing school plans, establishing regula-tions, and solving problems. The quality of education consists of aca-demic and non-academic achievements. The advice given to school principals is expected to maintain and further increase the involve-ment of teachers, parents, and the community in formulating school policies and programs.
\end{abstract}

Keywords: Special education, SLB, SBM, school-based management, education quality

\section{Introduction}

Education is the most basic human right, including children with special needs. It is because al school-age children were entitled to an educational program, meaning that students with special needs were no more separated from other students in terms of defining their basic right to an educational program (De Witte et al., 2019). The amended 1945 Constitution has provided guarantees to them as stated in Article 31 paragraph (1). According to Mudjito et al. (2013) The spirit of the 1945 Constitution above is in line with the call of the United Nations Educational Scientific and Cultural Organization (UNESCO) regarding International Education for All (EFA) which is a global agreement from the Forum in Dakar-Sinegal. The result is the agreement for the completion of the EFA. Furthermore, Tarmansyah (2007) explained that the government's policy in completing the compulsory education of nine years of basic education was announced by UNESCO as a global agreement as a result of the World Education Forum in Dakar Senegal.

The Education for All paradigm (education for all) is an effort to fulfill the need for education as a minimum human right at the basic education level. There needs to be a coalition of various parties to meet the basic education needs of all (adolescents and adults). In this sense, special education engages a group of children with increased utilization of services related to education (Sicen et al., 2007). The reasons that underlie countries in the world in 
realizing Education for All are the increasing workforce of children who have lost their education and their future.

Law Number 20 of 2003 concerning the National Education System and reinforced again in the Law of the Republic of Indonesia Number 8 of 2016 concerning Persons with Disabilities Article 40 paragraph (1) The Government and Local Governments are required to organize and/or facilitate education for persons with disabilities in each route, type, and level of education according to their authority.

The above indicates that the government provides expanded access to education for children with special needs and provides assurance and convenience in education, one of which is through special education or special education. This is following the statement in The Salamanca Statement and Framework for Action on Special Needs Education article 2 paragraph (3) which states that those with special needs must have access to schools that must accommodate them within the framework of child-centered pedagogy. which can meet these needs (Mudjito et al., 2013). To achieve this goal, it is important to identifying, enumer-ating, and locating the special population living community (Ringel et al., 2009), especially the children. The expansion of this opportunity is one of the government's efforts to improve the quality of education in our country.

More clearly, Hallahan and Kauffman (2006) have various options for providing education for children with special needs, namely: 1) regular class only; 2 ) regular class with consultation; 3) itinerant teacher; 4) resource teacher; 5) diagnostic-prescriptive center; 6) hospital or homebound instruction; 7) self-contained class; 8) special day school, and 9) residential school. Besides, the essential features of special educa-tion for students with learning disabilities are the influence of monitoring progress, providing explicit and systematic instruction, understand-ing the critical factors associated with progress in academic areas such as reading and math (Vaughn \& LinanThompson, 2003). Special Schools (SLB) are schools intended for children with special needs that cannot be matched with other children. Special Schools (SLB) consist of several types according to Pratiwi \& Murtiningsih (2013) namely: (1) Part A Special School, namely SLB for blind people; (2) Special Special School Part B, namely SLB for deaf people; (3) Special Special School Part C, namely SLB for mentally retarded patients; (4) Special School Part D, namely SLB for people with physical disabilities; (5) Special Special School Part E, namely SLB for people with disabilities; (6) Part G special schools are special schools for people with disabilities. Thus, funding is important as well to provide special schools for children with special need (De Witte et al., 2019b)

The government strives to improve the quality, efficiency, and equity of education in Indonesia by granting authority to local governments to manage several of their affairs independently, including one of which is education. Law Number 32 of 2004 concerning Regional Government has outlined that the granting of authority and discretion to the regions is intended to implement and regulate the interests of local communities according to their initiatives based on community aspirations following laws and regulations that mandate the delegation of authority from the central government to regional governments. This is in line with the fact that focusing on the environment and the role of practitioners has the potential to improve the inclusion out-comes for older learners with disabilities (Maciver et al., 2018).

School-Based Management (SBM) is an alternative to the concept of empowering schools. This is the case in special and inclusive education, based on the General Guidelines for the Implementation of Inclusive Education states that to optimize educational services in schools, the implementation of inclusive education in its management requires the following: 1) schools implement a management system school-based and 2) teachers can optimize the role of parents, professional staff, professional organizations, non-governmental organizations (NGOs) and school committees in learning activities in schools (Zakia, 2011). Besides, 
focusing on children attending school is important as well, for learning disabilities encompass varied dis-orders associated primarily with the difficulty of learning (Mather \& Ofiesh, 2005).

In special education that implements School-Based Management (MBS) to improve the quality of education. In the process, the Special School (SLB) increases the efficiency, quality, and equity of education. According to Mulyasa (2007), the School-Based Management Process, efficiency is obtained through the flexibility to manage existing resources, community participation, and simplification of the bureaucracy. Improved quality of education is obtained through parental participation, flexibility in school management, increased teacher professionalism, rewards and punishments as controls, and other things that can foster a conducive atmosphere. Equitable education can be seen in the growing participation of the community, especially those who are able and caring, while what is lacking will become the responsibility of the government.

The concept of improving the quality of school-based education appears within the framework of a school-based management approach. In essence, SBM will bring progress in two interdependent areas, namely, first, the intention of educational programs and services to parents, students parents, students, and the community. Second, the quality of the work environment for all members of the organization (Nurkolis, 2003). Hence, the edu-cators will need to make placement decisions considering the resources available in their school, in addition to the skill level of the stu-dents they work with, to make proper deci-sions regarding the least restrictive environ-ment (Ford, 2013).

In the relationship between School-Based Management (MBS) and improving the quality of education, Hasbullah (2006) explained that School-Based Management (MBS) is a management model that provides greater autonomy to schools and communities to meet school quality needs or achieve school quality objectives within the framework of National Education. Therefore, the essence of School-Based Management (SBM) is school autonomy with flexibility and participation to achieve education quality goals. Also, interventions are more effective at improving student perfor-mance and learning when social norms and in-tertemporal choices are factored into the design of education policies (Masino \& Nino-Zarzazua, 2016).

Indicators of the success of School-Based Management in special education were developed as follows:

Table 1. Indicators of the success of SBM in special education

\begin{tabular}{|c|c|}
\hline Dimensions & Indicator \\
\hline $\begin{array}{l}\text { The principal of SLB } \\
\text { School }\end{array}$ & Transparency (principle of openness) \\
\hline Class / teacher & PAKEM learning and enhancing the abilities of special students \\
\hline Curriculum & $\begin{array}{l}\text { Flexible, namely the official curriculum and local content } \\
\text { curriculum and according to the needs of students }\end{array}$ \\
\hline Society participation & $\begin{array}{l}\text { Joint decisions (policies) through the active participation of } \\
\text { parents in both committee forums, as well as activities with } \\
\text { parents and schools }\end{array}$ \\
\hline \multirow[t]{4}{*}{ School organization } & Provide management in achieving school goals \\
\hline & $\begin{array}{l}\text { Develop plans and formulate policies for schools in an } \\
\text { autonomous manner }\end{array}$ \\
\hline & Manage school operational activities \\
\hline & $\begin{array}{l}\text { There is effective communication between the school and the } \\
\text { community (school community) }\end{array}$ \\
\hline \multirow{2}{*}{ To be continued..... } & Organizing community participation \\
\hline & $\begin{array}{l}\text { Ensuring the maintenance of schools that are accountable to the } \\
\text { community and government }\end{array}$ \\
\hline
\end{tabular}




\begin{tabular}{|c|c|}
\hline Dimensions & Indicator \\
\hline \multirow[t]{4}{*}{$\begin{array}{c}\text { Administrative resource } \\
\text { management }\end{array}$} & $\begin{array}{l}\text { Identifying the resources needed and allocating these resources } \\
\text { according to school needs both administratively and learning }\end{array}$ \\
\hline & Manage the school environment \\
\hline & Provide administrative support \\
\hline & Manage and maintain buildings and other infrastructure \\
\hline \multirow[t]{4}{*}{$\begin{array}{c}\text { Teaching and learning } \\
\text { process }\end{array}$} & $\begin{array}{l}\text { Improve the quality of the PAKEM learning process and suit the } \\
\text { needs of students }\end{array}$ \\
\hline & $\begin{array}{l}\text { Developing a curriculum that is appropriate and responsive to } \\
\text { the needs of each student, community, and school }\end{array}$ \\
\hline & Carry out active teaching \\
\hline & $\begin{array}{l}\text { Providing development programs tailored to the needs and } \\
\text { abilities as well as the future of students }\end{array}$ \\
\hline \multirow[t]{5}{*}{$\begin{array}{c}\text { Human resource } \\
\text { conditions }\end{array}$} & $\begin{array}{l}\text { Empowering staff and placing personnel who can serve the } \\
\text { needs of students }\end{array}$ \\
\hline & Select staff who have skills in school-based management \\
\hline & Provide activities for achievement development for all staff \\
\hline & Ensure the welfare of staff and students \\
\hline & $\begin{array}{l}\text { Organizing forums or discussions to discuss school progress } \\
\text { (school performance) }\end{array}$ \\
\hline \multirow[t]{4}{*}{ Students } & There are no students who drop out, stay in class \\
\hline & Students attend school and are happy \\
\hline & Learning becomes the main focus \\
\hline & Increasingly explorative, creative, innovative, and integral \\
\hline
\end{tabular}

The impact or influence of SBM on schools to improve the quality of education, among others: SBM creates a high sense of responsibility for school members through more open school management. The openness of SBM increases the trust, motivation, and support of parents and the community for the school. The implementation of Active, Creative, Effective, and Fun Learning (PAKEM) will increase the percentage of student attendance at school because they feel happy and comfortable learning. Supporting adequate operational costs will support the implementation of programs that have been jointly arranged between the school and the community (Hamid, 2013). The researcher took the location at SLB-A Negeri 3 Martapura because the location was motivated by the suitability of the topic in this study, this location shows that the institution has implemented school-based management, especially in special schools.
The research objective of this research is to de-scribe in-depth and analyze in detail about: Describe in-depth and analyze in detail about: (1) applied school autonomy which includes performance opti-mization, management of learning resources, profes-sionalism of educational personnel, as well as facili-ties and infrastructure and types services to students and parents; (2) implementation of innovative learn-ing efforts made by schools in designing active, crea-tive, effective and fun teaching and learning process-es to enable students to learn smoothly and success-fully; implementation of participatory decisionmaking by school members, community organiza-tions and community members involved by schools in the education process at schools; (4) the achieve-ment of the quality of education in schools on the results of student graduation obtained during the period applied school-based management. 


\section{Material and Methods}

This study used a phenomenological qualitative descriptive approach with a case study design in SLB-A Negeri 3 Martapura, Banjar Regency. The subjects of this study were 10 teachers and school principals. The primary data sources in this study were the principal, teachers and this will be strengthened by the opinion of the committee and parents of students who were randomly selected as a secondary data source. The sampling technique used purposive sampling.

Data collection techniques used direct observation, in-depth interviews, and documentation. Data were analyzed using qualitative data analysis stages, namely data reduction, data display, and data verification. Data analysis using content analysis with Miles and Huberman's model. Testing the validity of the data used in this study in the analysis of research data, using techniques: credibility (degree of trust), dependability (dependence), and confirmability (certainty).

\section{Results and Discussion}

The application of School-Based Management encourages schools to be active, independent, open, and accountable through various programs to improve the quality of education according to the needs of the school independently adjusted to the needs and conditions of the school along with participatory decision making.

\section{Implementation of autonomy}

Autonomy or school authority in regulating and managing its school, independent of other parties. Independence in school programs and funding is the main measure of school independence which is continuously expected to ensure the sustainability of the school (Mahmud, 2015). Another opinion by the characteristics of school-based quality improvement management can be seen by how the school can optimize its performance. Some of the works that can serve as a reference are the learning process, management of learning resources, professionalism of education personnel, and the overall administrative system (Aziz, 2015). The implementation of school au- tonomy in SBM to improve the quality of education in SLB-A Negeri 3 Martapura with areas of authority to be observed include (1) optimization of school performance; (2) management of learning resources; (3) professionalism of educational personnel; (4) facilities and infrastructure; and (5) special services for students and parents of students.

The findings in SLB-A Negeri 1 Martapura regarding the optimization of school performance were that the principal provided discipline through online attendance through fingerprints. So that the principal can supervise teacher attendance and give warnings to teachers, the principal gives rewards to teachers in improving the quality of education in schools. The principal oversees the course of learning, the activities of teachers and students in learning, various ways to improve teacher discipline both attendance, learning tools, and the learning process.

This is in line with the findings of Hernita's (2018) research in School-Based Management (SBM) which is interrelated with the development of school culture and creating a positive culture in the school environment. this is formed with the discipline of students and teachers in the school environment. Another study by Ibrahim (2015) states that the principal in implementing SBM at SD Negeri Sakti Pidie has made planning, implementation, and disciplinary supervision of teachers and students run according to the provisions. Every school activity, both extracurricular and extracurricular activities, the principal always keeps an eye on its progress.

The findings regarding the management of learning resources are that learning resources at SLB-A Negeri 3 Martapura are complete and meet the needs of students in the form of books, magazines, books supporting literacy activities through poetry, learning media in the form of props, embossed maps, introduction to mathematics and emerging media and teacher innovation media as a learning medium. Completeness of books in the library is direct assistance from the government through BOS funds, the Mitra Netra foundation, and the BLBI Abiyoso Library in fulfilling braille books and other media for students. learning resources are fulfilled 
by the government, school committees, and donations from parties related to the provision of special education. The results of the research findings above are in line with the explanation from Sanjaya (2008) regarding the importance of learning resources in learning resource activities in learning activities. Learning resources relating to something that allows students to gain their learning experience, including the physical environment such as a place to learn and materials and tools for all personal use, be it teachers, librarians, or media experts, because anyone who influences directly or indirectly for success in the learning experience of course.

The findings regarding the professionalism of the education staff are on the specialists' teacher graduates, the equivalence of teachers who are not extraordinary graduates, and experienced as In House Training (IHT) trainers regarding the training activities they participate in. Teachers and school principals participate in national level competitions to improve competence and participate in international seminars. These findings are in line with research by Lawotan (2019) on the Implementation of School-Based Management (SBM) in improving teacher professional competence, the principal as a leader gives full responsibility to teachers to plan, implement and develop programs related to increasing their professional competence. School principals involve teachers in training activities (education and training), seminars, workshops, and technical guidance to broaden teachers' insights in increasing their professional competence through the implementation of School-Based Management (MBS). The quantitative findings by Junaidi (2017) show that teacher professionalism affects the implementation of School-Based Management. This means that if the professionalism of teachers is improved, the implementation of School-Based Management will run well. School-based quality improvement (MPMBS) requires teachers who have broad knowledge, maturity, and can move to improve the quality of education. Therefore, it is necessary to improve the professional quality of a teacher, both formally and informally. A formal improvement is an increase in quality through education in various courses, schools, or lectures at universities or other institutions related to their professional fields. Also, formally teachers can improve the quality of their profession by obtaining information from the mass media (newspapers, magazines, radio, television, etc.) or books following the relevant professional field.

The findings regarding the educational facilities, the condition of the facilities and infrastructure in SLB-A Negeri 3 Martapura are quite adequate, this can be seen from the classrooms with the number of students, the class conditions. The teacher room is integrated into the administration and operator room. Meanwhile, the principal's room becomes one building with the teacher's room. Another condition is that the teacher's room is more indented from the front fence so that if there are guests they have to go further, but the facilities and infrastructure do not affect the course of learning activities at SLB-A Negeri 3 Martapura. In line with the findings of Hijrah and Saway (2019) regarding facilities and infrastructure that influence the success of the learning process and maximize support for the achievement of successful education in schools, especially in the application of SBM. The implementation of the learning process involves several important aspects including facilities and infrastructure. Facilities and infrastructure function as support for the learning process or as facilities needed in the learning process to achieve effective and efficient educational goals.

The findings regarding special services for parents and students are that schools provide special services for new and transfer students by learning mobility and easy access to infrastructure in schools. Meanwhile, special services for low-class parents at the beginning of the school year are permitted to wait for the child while at school but are given 3 (three) months. The committee works closely with the school in providing knowledge to parents in providing services and education at home.

\section{Organizing creative and fun active learn-ing}

The MBS program is expected to create a school culture that encourages students to become skilled and responsible citizens. Through 
an active and par-ticipatory approach or PAKEM learning, children learn to cooperate well, have the courage to express their opinions politely and politely, are tolerant of accepting other people's opinions, and openness that will encourage someone to behave honestly. The school culture that you want to develop through SBM is: a) Religious Culture, b) Clean and Healthy, c) Po-lite and Courteous, d) Disciplined, e) Reading Cul-ture, and f) A Loving Culture of Saving (Mawardi, 2019). In the context of learning activities at schools with special needs, it consists of learning strategies and the role of teachers.

Findings regarding learning strategies regarding innovative strategies in the 2013 curriculum that were developed using educational programs for blind students. Learning devices are used with thematic learning but delivered in braille. The methods used are discussion, the direct practice of question and answer, drill, and Fernald's method with applied media to optimize other senses.

Strategies that are applied to increase independ-ence are things or circumstances that can stand alone without depending on others. According to Sriwi-jayanti (2017), independence (self-reliance) is a word that is easy to say but difficult to do, if you look at the measure of independence itself, you still have a different perception. Providing technology for blind people in the digital era like today. The work-ing system of providing technology to masters who play a role in increasing human resources in the eco-nomic sector and independence has been structured clearly and systematically. Technology provision can indirectly help blind people express their crea-tivity, opinion, experience, and inspiration in the field of writing. Also, the use of technology can make the teaching and learning process become more fun and help the students to improve their learning achievement (Dalle \& Mutalib, 2018).

In the implementation of learning activities in SBM, a professional teacher must first be able to plan a teaching program. Then carry out the teaching pro-gram properly and evaluate learning outcomes so that they can achieve learning objectives. Also, a pro-fessional teacher will produce students who can master knowledge in both cognitive, affective, and psychomotor aspects (Suprihatin, 2017). Another study by Trianto, Sumadi, \& Ambarita (2013) states that PAKEM activities at SMP Negeri 1 Palas are the right steps to achieve learning objectives because PAKEM can make students active and creative in participating in learning and feel happy. With a pleasant atmosphere, students find it easier to digest the material presented, students are more active and creative to build their knowledge (Purwanti, Suriansyah, Aslamiah, \& Dalle, 2018).

The strategy is applied by combining approaches and teaching methods to students that are centered on students, conveyed in a fun way, and with the hope that students can achieve certain abilities (competency-based learning). The strategy taught is the result of teacher innovation in improving the abilities of students and developing the talents of students with special needs. It is in line with the results of Adnan's (2017) research that the method construction in the learning process is the PAIKEM method which is known as learning, active, innovative, effective, and fun. For this reason, teachers as teaching staff can understand the urgency of this method so that learning in class will be better.

The findings regarding the role of teachers are in innovative learning, namely teachers as modifiers, facilitators, and mentors and motivators as well as conveying messages in learning media. Career guidance is carried out by the teacher as well as conveying existing media to students, the teacher also plays an active role, the teachers know how the school environment is as a facilitator to introduce literacy to students. This is following the opinion of Sardiman (2011) that teachers as mediators, teachers do not only act as mediators or provide a way out of all the ignorance of information that students feel, mediators can also be interpreted as media providers.

Findings regarding career guidance for children with special needs (blind) as a teacher's effort to provide further education or career continuity to students in the future. These findings are in line with the results of Kamaruddin's research (2019), namely the implementation of Career Guidance for Blind Children at 
the Pinrang Special School. About career guidance that seeks to provide opportunities for blind children, namely: academic guidance, vocal training, Al- reading, and writing guidance. Braille Qur'an, massage skills, learning services, content mastery services. In another study by Rofiah (2015) tutoring for children with special needs, the teacher must use the principles of guidance including the principles of the whole child, reality, dynamic, equal opportunity, and cooperation. As long as children with special needs are in education, guidance for mastering various skills according to the condition of his disability, mental abilities, talents, and interests. These skills will be a provision for his future life in society so that not all of his life depends on other people and can live naturally like other members of society.

\section{Community Participation Development}

The school's relationship with the community aims to maintain the continuity of the school, improve the quality of education, and get help and support from the community to develop and implement school programs (Warsilah \& Wijayanti, 2015). In fostering community participation in schools that implement School-Based Management, which consists of 1) fostering participation in parental / community mentoring; 2) fostering parental participation in school decision making; and 3) implementation of participatory decision policies.

The findings regarding fostering participation in parental / community mentoring are that they have made efforts to increase the responsibility and par-ticipation of the community in the delivery of educa-tion in schools. The committee assists schools in providing health services, skills, and training for independence to students. The committee assists schools by providing educational information and knowledge to parents about their students. The community helps students in accessing public facili-ties and other information. Assistance with certain parties by collaborating with students with Lambung Mangkurat University regarding the availability of the University in accepting blind students through disabilities. This finding is in line with the results of Ismail's (2008) research, namely the empowerment of all educational resources, including participation and empowerment of parents and communities to develop education. The existence of a school board (committee) that organizes the provision of facilities and contribution of thoughts and supervision in the management of education. SBM is implemented with the main purpose of improving the quality of educa-tion. Another study by Rizalie (2016) on participa-tory decision making involves school members and the community in decision making. The forms of decision making are as follows; (a) involving school members and the community as a whole, (b) involv-ing school members and school committees, (c) in-volving only school residents, and (d) involving on-ly the principal and vice-principal. The difference in the involvement of the parties in this decision mak-ing is influenced by (1) the scope of the problem to be resolved, (2) the availability of time for problem-solving, (3) the principal's leadership style, (4) past experiences.

School relations with the community through the school committee so that educational efforts are car-ried out optimally and in collaboration with the committee in providing educational services to stu-dents. It is in line with the results of Amanah \& Nurhikmahyanti's (2014) research that by implementing School-Based Management at SDN 2 Sidokumpul Gresik that is carried out in a transparent, independ-ent, open manner and establishes cooperation be-tween the school and the guardians of students. An-other study by Sulasmono \& Murjini (2017) by the performance of the school committee as an advisory agency at SD Negeri Sukomarto Jumo Temanggung is good. His active role is in providing consideration and input to school planning, program implementa-tion, and resource management. This improves aca-demic and non-academic achievements.

The findings regarding school decisionmaking in School-Based Management at SLB-A Negeri 3 Marta-pura implemented through the role of the school principal in implementing SBM were very important in decision making. At SLB A Negeri 3 Martapura always involves the community such as the commu-nity, school 
committees, and parents or guardians of students (paguyuban) in making decisions such as the admission of new students, student graduation, and determining KKM. Every school program and funds are always reported to the school committee, the school usually invites parents to the meeting. Through bulletin boards, reports, and school activity plans, schools usually inform the school program that has been implemented, and also provides a suggestion box so that the community cares and be-lieves in what the school is doing. However, only a part of the community participated in attending ac-tivities held by the school. This is in line with the results of Churdaini's (2020) research that school participation in improving the quality of education at SMP Negeri 17 Purworejo is carried out by involving related stakeholders. They are involved in planning and establishing school policies. Active participation or participation is needed to assist the implementa-tion of education.

The role of the principal has always been to try to apply the main principles of SBM, namely school autonomy and participation of school members in decision making and implementation (Lurah \& Haryanto, 2014). In the context of implementing school participatory decision policies, there are sev-eral actions that schools need to take to overcome problems or make guidelines in carrying out future work involving data by involving all school mem-bers following their respective duties. The areas in question are (a) school development plans; (b) es-tablishing school regulations, and (3) settlement of cases.

The findings regarding the school development plan were obtained from the school development plan for the SLB-A Negeri 3 Martapura, namely by involving school residents and the community through committees in making decisions and plan-ning educational programs so that schools could produce competitive students or educational out-puts. Document data that has been collected in school-based management environment activities are the vision, mission, objectives, activities, goals, and outputs to be achieved. Schools seek education for students by planning activity funds, improving teacher quality, and learning to foster interest in tal-ents and providing life skills to students.
This find-ing is in line with Muda's (2011) study of the prepa-ration of School-Based Management planning at the SLB Medan Child Development Foundation (YPAC) which has involved all stakeholders such as the teacher council, YPAC administrators, school com-mittees, and related agencies.

In the context of school-based management, school development plans, in general, have an im-portant role to play, namely: 1) the realization of good management; 2 ) implementation of quick and precise problem solving; 3) increasing pub-lic/community trust in educational institutions; 4) achieving independent, superior and competitive educational institutions; 5) schools continue to exist and develop; 6) increased productivity and perfor-mance of educational institutions; 7) and helps direct the institution towards achieving its vision, mission, and goals (Tarsan, 2018).

Efforts to involve school members and the com-munity through committees in education program planning. The committee assists schools in provid-ing health services, skills, and training for independ-ence to students. The committee also assists by providing educational information and knowledge to parents about their students. This is in line with the quantitative results of Waluyo and Hadi's (2014) research, namely the application of school-based management (SBM), learning management, and school committee participation together have a sig-nificant effect on the quality of SD / MI education. The contribution of the implementation of school-based management (SBM), learning management, and school committee participation together to the quality of SD / MI education was 58.9\%.

The findings regarding the stipulation of school regulations that school residents at SLBA Negeri 3 Martapura carry out picket duties, obey discipline in school, both discipline and attendance accuracy through class attendance, punctuality of arrival of teachers through online attendance so that they can be given reprimands, warnings, and deductions in attendance fees. Teachers carry out their duties and roles with a predetermined time, and teachers are required not to leave their teaching duties and obligations so that if they cannot attend, 
they can replace them temporarily. This is following the opinion of Salim (2013) which states that people who have high discipline are people who are always present on time, obey the rules, behave following prevailing norms both from society (conventional-informal), government or regulations set by a particular institution (formal-organization). The results of the study are in line with these findings by Jamil (2016), the supporting factors in the implementation of school-based management at Darul Imarah Public High School 1, Aceh Besar District, are examples of teachers in terms of discipline making students disciplined in obeying school regulations.

The finding regarding the resolution of cases is that it is the access of parents to the educational needs of students so that children are of a mature age to enter the class. The solutions provided by students are given a place to live in the committee house by providing facilities and infrastructure according to the needs of students. Providing understanding, motivation, and support regarding children's needs in education and children's future. The results of this study are in line with the research of Alamsyah et al. (2019) case resolution at SDN Alalak Selatan 2, namely There is a problem that is differences in attitudes for children who attend learning; and SDN Alalak Selatan 4, namely found a problem, the frequent occurrence of commotion in school. To realize School-Based Management, it is necessary to be supported by community development in the school. As stated by Muhaimin (2003), the school community means all school members who always try to: (1) pursue and develop skills or expertise continuously according to their field/task; (2) commitment to quality; (3) have and develop a sense of moral, social, intellectual and spiritual responsibility; and (4) have and develop a sense of serviceability or teamwork that is smart, dynamic and compact.

\section{Quality of education}

The quality of education focuses on outstanding students and the results of students' graduation at SLB-A Negeri 3 Martapura; (1) Academic Quality; and (2) Non-Academic Quality.
The findings regarding the achievement of the quality of education in SBM at SLB-A Negeri 3 Martapura is that the passing rate of SLB A Negeri 3 Martapura is always maintained, with a passing rate of $100 \%$ from year to year by providing extracurricular guidance to students, even outside working hours. This year, SLB A Negeri 3 Martapura managed to get a good ranking in the UN results that are equivalent to that of top schools. The results of the study are in line with Fauzi's research (2019) in the Implementation of School-Based Management (MBS) at SMP 10 November Sidoarjo, seen from the management of school components that have been carried out well. Furthermore, this increases student achievement, both academic and non-academic. From the comparison of the acquisition of the National Exam Score (NUN) before the implementation of Management, there was a significant increase. This proves that the implementation of School-Based Management (MBS) influences increasing student achievement.

Findings regarding the quality of non-academic education, namely through scout extracurricular learning and self-development, SLBA Negeri 3 Martapura won 1st place in 2020 in a national poetry creation competition held online, another provincial level competition in 2020 by winning 1 st place in storytelling competitions, creative writing, copying and reading poetry. In 2018, at the national level, 2nd winner in copyright and poetry reading competition, 3rd place in a creative writing competition, 2nd place in a chess competition, 1st place in MTQ competition, 3rd place in table tennis competition. In 2017, at the 2nd place in the Paralympic Week blind table tennis competition for national students. This research is in line with Saade (2011) in the results of research on School-Based Management (MBS) at SLB in Malang Regency in implementing school programs there is an increase, especially in aspects, namely the skills of children with special needs, student learning achievement, and nonacademic achievement. The increase in the quality of education in special schools is supported by community participation in school management, also supported by high commu- 
nity participation. It appears that the leadership of the principal in School-Based Management (SBM) has been managed in a transparent (open) and accountable manner.

\section{Conclusion and Recommendation}

The findings according to the focus of the study can be concluded that:

The applied school autonomy includes, (1) opti-mizing performance through teacher discipline with fingerprint online attendance; (2) managing learning resources by using libraries and computer rooms as learning resources and extracurricular spaces as places to foster students' interests and talents; (3), the professionalism of education personnel, namely teachers who teach following the ability to educate in special education through training, coaching, and educational equality, as well as facilities and infra-structure that meet the needs of students; (5) special services for parents and new students in accessing education.

Implementation of learning through innovative strategic strategies in the 2013 curriculum which was developed using educational programs for blind students; and the role of the teacher; as a modifier, facilitator, and mentor, and motivator as well as conveying messages in learning media. Career guid-ance through further education and future careers.

Implementing participatory decision-making pol-icies through (1) mentoring parents and communi-ties, namely by assisting with active communication and community assistance through committees; (2) school decision making through self-development activities, admission of new students, student gradu-ation, and determining KKM. Activity fund reporting; (3) participatory policy decisions include; (a) a school development plan by producing quality grad-uates, religious who are faithful and devout, honest, tolerant, disciplined, hard work, creative, independ-ent, democratic, love the country, are friendly, love peace, care for the environment, care socially and are responsible, as well as having a creative economy and entrepreneurial skills as a provision for independence in society and to continue to a higher level; (b) establishing disciplinary rules with punishment and reward for all school members; (c) understand-ing parents and society about children with special needs and access to special education for students with visual impairments.

Achievement of the quality of education in schools at (1) academic quality by successfully passing $100 \%$ of students and (2) non-academic quality successfully by obtaining achievements in every sport and literacy abilities of students.

\section{Acknowledgment}

The author thanked the Head of the Banjar Regen-cy Education Office, the school principal and staff at SLB-A Negeri 3 Martapura, and all the teaching staff at Lambung Mangkurat University.

\section{References}

Adnan, M. (2017). Urgensi penerapan metode paikem bagi guru dalam meningkatkan mutu pembelajaran pendidikan agama islam. CENDEKIA: Jurnal Studi Keislaman, 3(1), 133150.

Alamsyah, Aslamiah, \& Rizalie, A. M. (2019). School based management implementation to improve school quality of multi sites study in SDN Alalak Selatan 2 and Sdn Alalak Selatan 4 Banjarmasin City. International Journal of Scientific Development and Research (IJSDR), 4(1), 133-139. Retrieved from

https://www.ijsdr.org/papers/IJSDR1901022.pdf

Amanah, S., \& Nurhikmahyanti, D. (2014). Implementasi manajemen berbasis sekolah untuk meningkatkan prestasi belajar siswa di SDN 2 Sidokumpul Gresik. Jurnal Inspirasi Manajemen Pendidikan, 3(3), 124-132. Retrieved from https://jurnalmahasiswa.unesa.ac.id/index.php/inspirasi -manajemen-pendidikan/article/view/6635/7369

Aziz, A. Z. (2015). Manajemen berbasis sekolah:alternatif peningkatanmutu pendidikan madrasah. el-tarbawi, 8(1), 69-92. doi:10.20885/tarbawi.vol8.iss1.art5

Churdaini, M. (2020). Implementasi manajemen berbasis sekolah untuk meningkatkan mutu pendidikan di SMP Negeri17 Purworejo. Cakrawala: Studi Manajemen Pendidikan Islam Dan Studi Sosial, 4(1), 21-33. doi:https://doi.org/10.12345/cakrawala.v4i1.208

Dalle, J., \& Mutalib, A. A. (2018). The impact of technologies in teaching interaction design. Journal of Advanced Research in Dynamical and Control Systems, 4(special issue), 17791783.

De Witte, K., Titl, V., Holz, O., \& Smet, M. (2019). Overview of education systems. In Financing Quality Education for All: The Funding Methods of Compulsory and Special Needs 
Education (pp. 25-40). Leuven (Belgium): Leuven University Press.

De Witte, K., Titl, V., Holz, O., \& Smet, M. (2019b). Funding formulas. In Financing Quality Education for All: The Funding Methods of Compulsory and Special Needs Education (pp. 41-128). Leuven (Belgium): Leuven University Press.

Fauzi, F. (2019). Implementasi manajemen berbasis sekolah (mbs) dalam peningkatan prestasi belajar siswa di SMP 10 Nopember Sidoarjo. TARBAWI: Jurnal Pendidikan, 8(1), 6176. doi:10.36781/tarbawi.v8i1.3052

Ford, J. (2013). Educating Students with Learning Disabilities in Inclusive. Electronic Journal for Inclusive Education, Vol. 3 (1) (Fall, 1-20.

Hallahan, D. P., \& Kauffman, J. M. (2006). Exceptional Children: An Introduction to Special Education (10th ed.). Boston: Pearson.

Hamid. (2013). Manajemen berbasis sekolah. Al-Khawarizmi Jurnal Pendidikan Matematika dan Ilmu Pengetahuan Alam, 1(1), 87-96. doi:10.24256/jpmipa.v1i1.86

Hasbullah. (2006). Otonomi Pendidikan "Kebijakan Otonomi Daerah dan Implikasinya Terhadap Penyelenggaraan Pendidikan". Jakarta: Raja Grafindo Persada.

Hernita, R. (2018). Kepemimpinan kepala sekolah dalam mengembangkan budaya sekolah melalui manajamen berbasis sekolah. JMKSP: Jurnal Manajemen, Kepemimpinan dan Supervisi Pendidikan, 3(2), 261-269. doi:10.31851/jmksp.v3i2.1866

Hijrah, M., \& Saway, M. (2019). Manajemen pengembangan sarana dan prasarana dalam implementasi manajemen berbasis sekolah di MA Al-Falah Nagreg. MANAZHIM: Jurnal Manajemen dan Ilmu Pendidikan, 1(2), 72-103. doi:10.36088/manazhim.v1i2.205

Ibrahim. (2015). Implementasi manajemen berbasis sekolah pada SD Negeri Sakti Pidie. Jurnal Administrasi Pendidikan Program Pascasarjana Unsyiah (JAP PPS-Unsyiah), 3(1), 116-125. Retrieved from https://media.neliti.com/media/publications/72474-IDimplementasi-manajemen-berbasis-sekolah.pdf

Ismail, F. (2008). Manajemen berbasis sekolah: solusi peningkatan kualitas pendidikan. Jurnal Ilmiah IQRA', 2(2). doi:10.30984/jii.v2i2.541

Jamil, T. M. (2016). Implementasi manajemen berbasis sekolah (MBS) PADA Sekolah Menengah Atas Negeri di Kabupaten Aceh Besar. Jurnal Seuneubok Lada, 3(2), 1-11. Retrieved fromhttps://ejurnalunsam.id/index.php/jsnbl/article/vie $\mathrm{w} / 631 / 471$

Junaidi. (2017). Pengaruh kepemimpinan transformasional kepala sekolah dan profesionalisme guru terhadap implementasi manajemen berbasis sekolah pada pesantren DI Kabupaten Agam. Jurnal Tarbiyah, 24(2), 266-288. doi:10.30829/tar.v24i2.194

Kamaruddin. (2019). Bimbingan karir terhadap anak tuna netra: studi kasus di Sekolah Luar Biasa Negeri Pinrang. Indonesian Journal of Islamic Counseling (IJIC), 1(1), 56-76. Retrieved from http://ejurnal.iainpare.ac.id/index.php/ijic/article/view/ $\underline{789 / 563}$

Lawotan, Y. E. (2019). Implementasi manajemen berbasis sekolah (mbs) dalam meningkatkan kompetensi profesional guru di SD Katolik 143 Bhaktyarsa Maumere. Jurnal Pendidikan, 10-20. doi:10.36232/pendidikan.v7i2.297

Lurah, I. H., \& Haryanto. (2014). Peran kepala sekolah dalam penerapan manajemen berbasis sekolah (mbs) di SDIT Jabal Nur Gamping, Sleman. Jurnal Akuntabilitas Manajemen Pendidikan, 4(4), 174-187. doi:10.21831/amp.v2i2.2447

Maciver, D., Hunter, C., Adamson, A., Grayson, Z., Forsyth, K., \& McLeod, I. (2018). Supporting successful inclusive practices for learners with disabilities in high schools: a multisite, mixed method collective case study. Disability and Rehabilitation, 40:14, 1708-1717.

Mahmud, H. (2015). Administrasi pendidikan: menuju sekolah efektif. Jakarta: Aksara Timur.

Masino, S., \& Nino-Zarzazua, M. (2016). What works to improve the quality of student learning in developing countries? International Journal of Educational Development, Vol. 42 , 53-65.

Mather, N., \& Ofiesh, N. (2005). Resilience and the Child with Learning Disabilities. In B. R. Goldstein S., Handbook of Resilience in Children. Springer, Boston, MA.

Mawardi, A. D. (2019). Evaluasi pelaksanaan manajemen berbasis sekolah di Sekolah Dasar Negeri Kebun Bunga 6 Banjarmasin Timur menggunakan model cipp. Prosiding Seminar Nasional PS2DMP ULM. 5, pp. 15-24. Banjarmasin: Universitas Lambung Mangkurat. Retrieved from https://www.rumahjurnal.net/index.php/PS2DMP/articl e/view/778

Muda, I. (2011). Implementasi manajemen berbasis sekolah pada sekolah luar biasa (slb) ypac medan. PERSPEKTIF: Jurnal Ilmu Sosial-Fakultas ISIPOL IMA, 4(2), 85-90. doi:10.31289/perspektif.v1i2.85

Mudjito, Harizal, \& Elfindri. (2013). Pendidikan inklusif. Jakarta.: Badouse Media.

Muhaimin. (2003). Wacana pengembangan pendidikan islam. Surabaya: Pustaka Pelajar.

Mulyasa, E. (2007). Manajemen Berbasis Sekolah: Konsep, Strategi dan Implementasi. Bandung: Remaja Rosdakarya. 
Nurkolis. (2003). Manajemen berbasis sekolah: teori, model dan aplikasi. Jakarta: Gramedia Widiasarana Indonesia.

Pratiwi, R. P., \& Murtiningsih, A. (2013). Kiat sukses mengasuh anak berkebutuhan khusus. Yogyakarta: Ar-Ruzz Media.

Purwanti, R., Suriansyah, A., Aslamiah, A., \& Dalle, J. (2018). Introducing language aspect (English) to early childhood through the combination of picture and picture model, talking stick model, flashcard media, and movement and song method in B1 group at Matahariku bilingual kindergarten Landasan Ulin Tengah . European Journal of Education Studies, 26-34.

Ringel, J., Chandra, A., Williams, M., Ricci, K., Felton, A., Adamson, D., \& . . . Huang, M. (2009). Core Strategies to Enhance Emergency Preparedness Planning and Response for Special Needs Populations. In Enhancing Public Health Emergency Preparedness for Special Needs Populations: A Toolkit for State and Local Planning and Response (pp. 1928). RAND Corporation.

Rizalie, A. M. (2016). Implementasi manajemen berbasis sekolah untuk peningkatan mutu pendidikan di sekolah dan madrasah menengah atas (studi multi kasus Pada SMA Negeri 1, SMK Negeri 2 dan MA Negeri 1 Kandangan Kabupaten Hulu Sungai Selatan). PARADIGMA, 11(2). Retrieved from https://ppjp.ulm.ac.id/journal/index.php/paradigma/arti cle/view/2691/2344

Rofiah, N. H. (2015). Bimbingan belajar untuk anak berkebutuhan khusus di sekolah dasar. Prosiding Seminar Nasional dan Call for Papers Pendidikan Guru Sekolah Dasar UMS 2015 (pp. 254-262). Solo: Universitas Muhammadiyah Surakarta.

Saade, K. (2011). Program manajemen berbasis sekolah (mbs) implementasinya pada prestasi sekolah dasar di Kabupaten Bantaeng, Sulawesi Selatan. Jurnal Administrasi Publik, 2(1), 16-29. Retrieved from https://media.neliti.com/media/publications/97351-IDprogram-manajemen-berbasis-sekolah-mbs-i.pdf

Salim, M. H. (2013). Pendidikan karakter: konsepsi \& implementasinya. Yogyakarta: Ar-Ruzz Media.

Sanjaya, W. (2008). Perancangan dan desain sistem pembelajaran. Jakarta: Kencana Prenada Media Group.

Sardiman. (2011). Interaksi dan motivasi belajar mengajar. Jakarta: Raja Grafindo Persada.

Sices, L., Harman, J., \& Kelleher, K. (2007). Health-Care Use and Expenditures for Children in Special Education with Special Health-Care Needs: Is Dual Classification a Marker for High Use? Public Health Reports (1974-), 122(4), 531540 .

Sriwijayanti, R. P. (2017). Model pendidikan teknologi kepada penyandang tunanetra sebagai kemandirian dan sumber penghasilan di SMPLB Sinar Harapan Kota Probolinggo
Tahun 2017. Prosiding Lomba Karya Tulis Ilmiah Guru SMA/Sederajat dan Dosen Se-Jawa Timur Tahun 2017 (pp. 138-145). Malang: Pusat Studi dan Layanan Disabilitas (PSLD) Universitas Brawijaya. Retrieved from https://fib.ub.ac.id/wp-content/uploads/2020/03/EmySudarwati Penerapan-Metode-Pembelajaran-KooperatifCooperative-Learning-Untuk-Meningkatkan-SikapBerpikir-Kritis-Mahasiswa-Difabel-Pada-Mata-KuliahCritical-Reading.pdf

Sulasmono, B. S., \& Murjini. (2017). Evaluasi kinerja komite sekolah dalam meningkatkan mutu pendidikan. Cakrawala Pendidikan: Jurnal Ilmiah Pendidikan, 36(1), 113-121. doi:https://dx.doi.org/10.21831/cp.v36i1.10431

Suprihatin, B. (2017). Meningkatkan profesionalisme guru melalui implementasi manajemen berbasis sekolah (MBS) di SD Sahara Kabupaten Bandung. Jurnal Ekonomi, Bisnis \& Entrepreneurship, 11(2), 89-98. Retrieved from http://jurnal.stiepas.ac.id/index.php/jebe/article/view/2 $\underline{00 / 262}$

Tarmansyah. (2007). Pendidikan inklusi untuk semua. Jakarta: Departemen Pendidikan Nasional.

Tarsan, V. (2018). Rencana pengembangan sekolahdalam konteks manajemen berbasis sekolah (mbs). Jurnal Pendidikan dan Kebudayaan Missio, 10(1), 107-118. Retrieved

from http://unikastpaulus.ac.id/jurnal/index.php/jpkm/articl e/view/62/47

Trianto, K. J., Sumadi, \& Ambarita, A. (2013). Sinergisitas sekolah, masyarakat dan pemerintah dalam implementasi manajemen berbasis sekolah (MBS). JMMP: Jurnal Manajemen Mutu Pendidikan, 1(2), 1-5. Retrieved from http://jurnal.fkip.unila.ac.id/index.php/IMMP/article/vie $\mathrm{w} / 2257$

Vaughn, S., \& Linan-Thompson, S. (2003). What Is Special About Special Education for Students with Learning Disabilities? The Journal of Special Education, 37(3), 140-147.

Waluyo, G. E., \& Hadi, S. (2014). Pengaruh penerapan mbs, pengelolaan pembelajaran dan partisipasi komite sekolah terhadap mutu pendidikan sd/mi. Jurnal Akutabilitas Manajemen Pendidikan, 2(2), 159-173. doi:10.21831/amp.v2i2.2446

Warsilah, \& Wijayanti, W. (2015). Peran kepala sekolah dalam pengembangan budaya sekolah di UPT SD kecamatan Moyu dan kabupaten Sleman. Jurnal Akuntabilitas Manajemen Pendidikan, 3(1), 97-113. doi:https://doi.org/10.21831/amp.v3i1.6273

Zakia, D. L. (2011). Pedoman Umum Penyelenggaraan Pendidikan Inklusif (Sesuai Permendiknas No 70 Tahun 2009). Jakarta: Direktorat PPK-LK Pendidikan Dasar Kementerian Pendidikan Dan Kebudayaan. 